U. S. GEOLOGICAL SURVEY

Field Library

Albuquerque, New Mexico

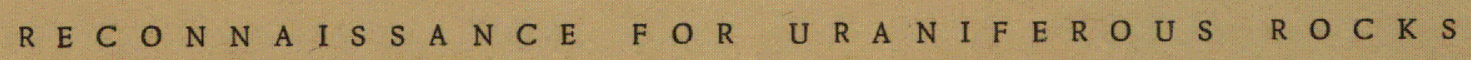

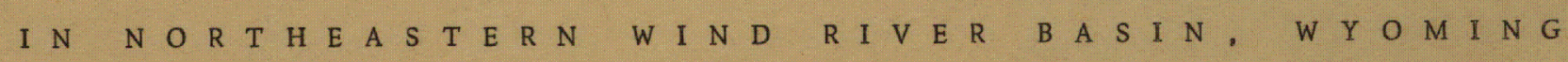

Trace Elements Memorandum Report 445

UNITED STATES DEPARTMENT OF THE INTERIOR

GEOLOGICAL SURVEY 
$x^{2}$

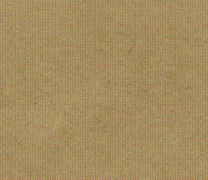

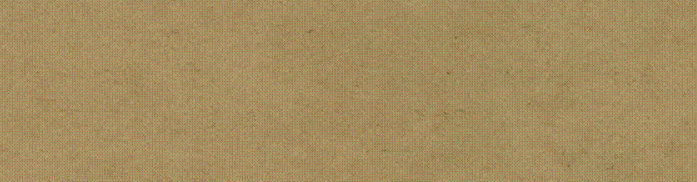

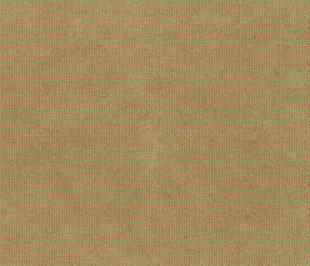

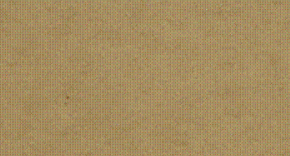

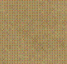


American Cyanamid Company, Watertown. . . . . . . . . . . . . . . . . . . 1

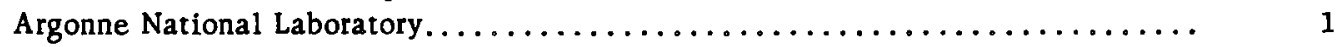

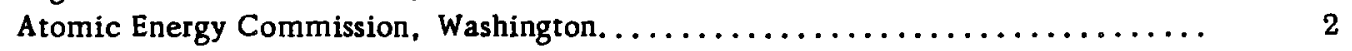

Carbide and Carbon Chemicals Company, $\mathrm{Y}-12$ Area. . . . . . . . . . . . . . . . 1

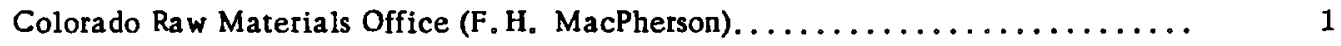

Division of Raw Materials, Grand Junction. . . . . . . . . . . . . . . . . . . 1

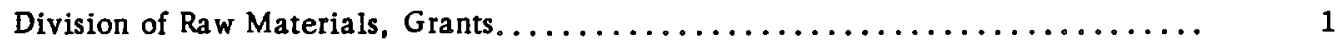

Division of Raw Materials, Denver. ......................... 1

Division of Raw Materials, Hot Springs. . . . . . . . . . . . . . . . . . . 1

Division of Raw Materials, New York. ......................... 6

Division of Raw Materials, Salt Lake City. . . . . . . . . . . . . . . . . . . . 1

Division of Raw Materials, Richfield. ......................... 1

Division of Raw Materials, Butte.............................. 1

Division of Raw Materials, washington. . . . . . . . . . . . . . . . . . . .

Dow Chemical Company, Pittsburg. ......................... 1

Technical Information Service, Oak Ridge. .................... 6

Battelle Memorial Institute, Columbus. . . . . . . . . . . . . . . . . . . 1

Tennessee Valley Authority, Wilson Dam....................... 1

U. S. Geological Survey:

Mineral Deposits Branch, Washington. ....................... 1

Geochemistry and Petrology Branch, Washington. .................. 1

Geophysics Branch, Washington. .......................... 1

Alaskan Geology Branch, washington. ....................... 1

Fuels Branch, Washington. . . . . . . . . . . . . . . . . . . . . . . . . .

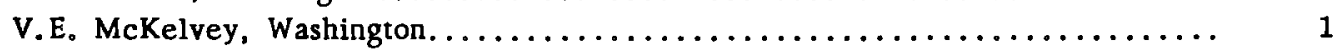

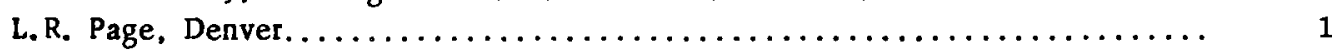

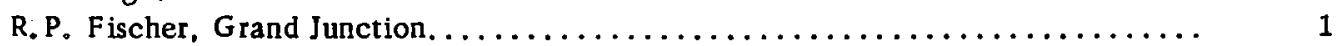

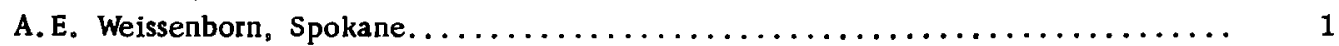

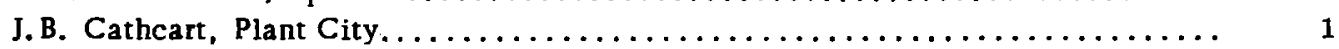

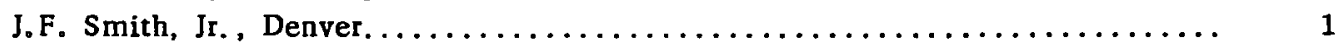

N. M. Denson, Denver. .............................. 1

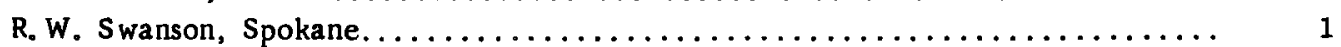

C. B. Read, Albuquerque. ............................... 1

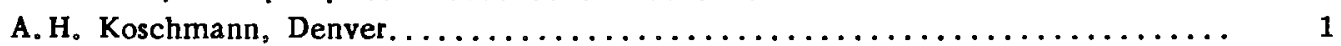

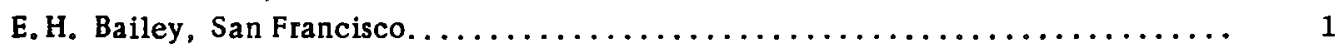

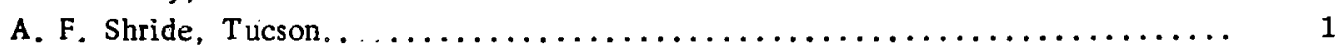

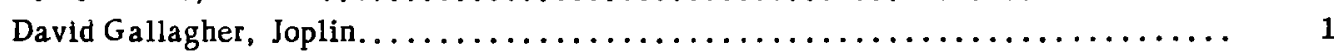

Carl Dutton, Madison. ............................... 1

R. A. Laurence, Knoxville. ............................. 1

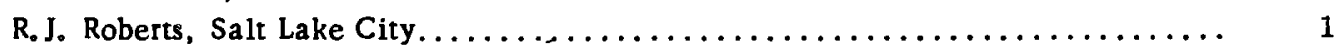

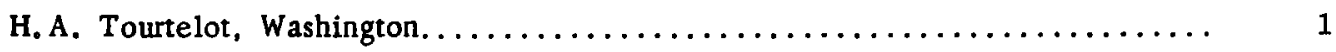

TEPCO, Washington $\ldots \ldots \ldots \ldots \ldots \ldots \ldots \ldots \ldots \ldots \ldots \ldots \ldots \ldots \ldots \ldots \ldots \ldots \ldots$

(Including master) 
CONTENTS

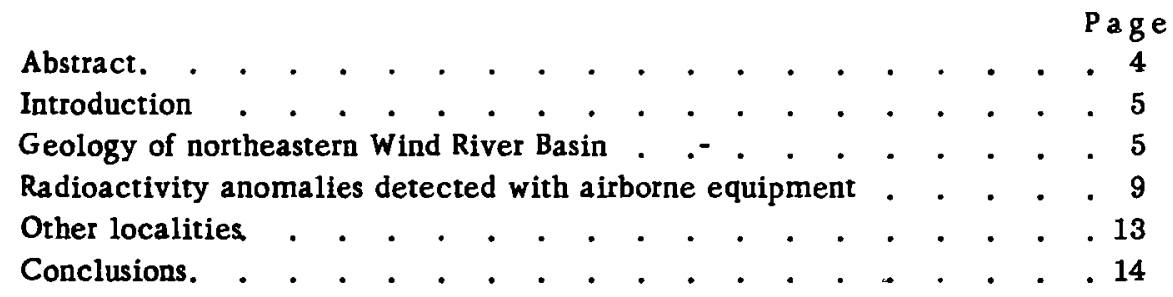

\section{ILLUSTRATIONS}

Figure 1. Sketch map of northeastern part of Wind River Basin, Wyoming, showing localities checked in 1951 with field counter and the area covered by Figure 2 .

2. Geologic map of Dry Creek area showing radioactivity anomalies detected from air . . . . . . . . . . 10

T ABLE

Table 1. Air-detected anomalies . . . . . . . . . . . . . 12 


\title{
RECONNAISSANCE FOR URANIFEROUS ROCKS \\ IN NORTHEASTERN WIND RIVER BASIN, WYOMING
}

By $H_{0}$ A. Tourtelot

\begin{abstract}
A B S T RACT
A reconnaissance search for uraniferous rocks in the northeastern part of the Wind River Basin was made in July and August 1951 in the course of other work. In addition to Tertiary tuffs and associated lignite, coal, and carbonaceous rocks, some radioactivity anomalies, chiefly in granite, which had been detected by airborne equipment in November 1950, were checked on the ground. A tuff of middle or late Eocene age containing 0.003 percent uranium was as high in uranium as any rock found. One sample of granite also contained 0.003 percent uranium. The equivalent uranium content of the granite was two to five times as large as the uranium content, presumably due to the presence of thorium. Further investigations in the northeastern part of the basin do not seem to be warranted at the present time, but more reconnaissance testing will be done whenever work on other materials is undertaken there.
\end{abstract}




\section{INTRODUCTION}

In connection with other geologic work in the northeastern Wind River Basin, a field counter was used to test Tertiary tuffs and associated lignite, coal, and carbonaceous shale for radioactivity. The testing was not done systematically but only as opportunity was afforded where conditions believed to be favorable for the occurrence of uranium were found. Uraniferous rocks were not known to occur in the northeastern part of the Basin, but the area was considered worthy of airborne reconnaissance in connection with an airborne magnetometer survey made in November 1950.. Aerial photographic mosaic, showing the location of radioactivity anomalies of four orders of magnitude, was made available by Frank W. Stead, in charge of airborne radiation surveys for Trace Elements and W. J. Dempsey, Geophysics Branch, who was in charge of the flying. Approximately three days in August 1951 were spent in ground examination of the radioactivity anomalies which had been found in the airborne reconnaissance. The general area in which work was done is shown in figure 1.

\section{GEOLOGY OF NORTHEASTERN WIND RIVER BASIN}

The Wind River Basin is a large structural depression partly filled with Tertiary rocks. It is bordered by anticlinal mountain ranges on the north, west, and south, and by a steep monocline and associated anticlines on the east. The central part of the basin is filled with sediments that are assigned to the Wind River formation of early Eocene age but a narrow band of middle and upper Eocene and younger rocks flank the mountains along the northeastern border of the basin. The middle Eocene and younger rocks are as much as 500 feet thick and are predominantly tuffaceous throughout most of their extent. In large areas near the mountains, the middle and upper Eocene strata consist of material eroded from the pre-Tertiary rocks of the mountains. The locally derived rocks that are near the mountain front grade laterally into tuffaceous rocks and tuffs a short distance away from the mountains. The rocks that are locally derived extend farthest into the basin in the lower part of the middle and upper Eocene sequence; at some places, tuffs in the upper part of the sequence overlap the pre-Tertiary rocks of the mountains.

Lysite Mountains, a plateau that is remnant of previously more extensive Tertiary rocks,forms part of the drainage divide between the Wind River and Bighorn Basins and lies across the syncline between the 
Ow1 Creek and Bighorn Mountains. The Tertiary rocks consist of a lower unit of oil shale, coal, and tuff of possible middle Eocene age that is about 200 feet thick. This unit is overlain by about 600 feet of fine-grained to coarse-grained tuffs of middle and upper Eocene age.

The Owl Creek and Bighorn Mountains make up the northeast border of the basin. The mountains are large anticlines with Paleozoic rocks and some Mesozoic rocks exposed along their flanks. Along the eastern part of the Owl Creek Mountains, Paleozoic rocks are exposed mostly in inliers, the middle and upper Eocene sequence overlapping the pre-Cambrian rocks.

Lithologic characteristics of the Mesozoic and Paleozoic formations as determined from exposures in and near the Owl Creek Mountains are summarized below:

Mesozoic Rocks

Upper Cretaceous

Cody shale - gray to dark-gray marine shale with minor amounts of sandstone. 4000 feet.

Frontier formation - interbedded sandstone and shale. 850 feet.

Lower Cretaceous

Mowry shale - light gray siliceous shale. 360 feet.

Thermopolis shale - dark-gray to black shale with Muddy sandstone member near middle. 380 feet.

Lower Cretaceous and upper Jurassic

Cloverly and Morrison formations, undivided-variegated shale and mudstone with sandstone and conglomerate. $400-450$ feet.

Upper Jurassic

Sundance formation - upper unit of glauconitic shale, sandstone and limestone and lower unit of non-glauconitic sandstone and shale. 320 feet.

Middle Jurassic

Gypsum Spring formation - red shale and siltstone, white gypsum and thin beds of dolomite. 0-180 feet.

Triassic

Chugwater formation - red siltstone and sandstone with Alcova limestone member in upper part. 955 feet. 
Dinwoody formation - gypsum in upper part and ocher-colored siltstone in lower part.

80 feet.

Paleozoic Rocks

Permian

Phosphoria formation - dolomite, limestone, and dolomitic shale. 210 feet.

Carboniferous

Pennsylvania

Tensleep sandstone - gray to tan and brown fine-grained to coarse-grained sandstone 370 feet.

Amsden formation - dolomite in upper part; red shale and siltstone in middle part, and brown sandstone in lower part. 240 feet.

Mississippian

Madison formation - limestone, limy dolomite, and dolmite. 465 feet.

Ordovician

Bighorn dolomite - massive, cliff-forming, cream-colored dolomite with thin Lander sandstone at base. $20-140$ feet.

Cambrian

Gallatin limestone - glauconitic gray and tan limestone, lime pebble conglomerate, and limy shale with Maurice limestone member at base. 455 feet.

Gros Ventre formation - gray and grayish-green shale with thin beds of limestone-pebble conglomerate in upper part and glauconitic sandstone in lower part. 400 feet.

Flathead sandstone - coarse-grained to fine-grained brown and tan sandstone that locally is quartzitic; pebbly at base. 260 feet.

The pre-Cambrian rocks in the Owl Creek Mountains west of the Bighorn River are chiefly gneiss and schist that have been intruded by many dikes of basic rock. Near the Bighorn River, metasediments and dark schist are prominent. To the east, these rocks are largely replaced by granite that appears to have 
intruded the schist.

The Owl Creek and Bighorn Mountains were folded and faulted in late Cretaceous to early Tertiary time. The overlapping Tertiary rocks also are folded and faulted, the middle and upper Eocene unit have been preserved in its present position by being dropped down against the Wind River formation along the north side of faults paralleling the mountain front. At some places, these post-Eocene faults cut the pre-Tertiary rocks as well.

\section{RADIOACTIVITY ANOMALIES DETECTED WITH AIRBORNE EQUIPMENT}

The radioactivity anomalies detected with airborne equipment are shown in figure 2 . The area surveyed includes the Dry Creek drainage and vicinity, where the streams leave the south side of the Owl Creek Mountains to enter the Wind River Basin and also a part of the north slope of the mountains which drains into the Bighorn Basin. Twelve flight lines were flown east-west at $1 / 4$ and $1 / 2$ mile intervals in the eastern part of the area. One flight line was also flown north-south about 4 miles to the west along the west side of the Dry Creek area. The anomalies were segregated into 1st order (sharp peak), 2nd order (peak), 3rd order (broad peak), and 4th order (very broad peak), from highest to lowest, by comparison within this group of . anomalies rather than with reference to any absolute scale of orders of magnitude.

As the magnitude of the anomalies was not great enough to justify correction of the measurements for all variable factors, the location of each anomaly was plotted directly on the photomosaic base map at the point vertically below the aircraft at the maximum value of the anomaly. As airborne radioactivity measurements at a nominal 500-foot flight level reflect the total radiation from an area of about 1,000 -foot radius, the true location of a given anomaly, possibly representative of a very small area of much greater-thannormal radioactivity, might be as much as a quarter mile from the plotted or apparent location of the anomaly to either side of the flight path of the aircraft. Also, the location of anomalies on a base map required the assumption of straight-line flight and constant ground speed between recognizable points on photographic or other base maps in plotting of flight data. Thus, if the distance between such points is large, the error in estimated location midway between the points may be considerable. In this particular survey, the plotted location of anomalies might be in error by as much as 400 feet along the flight path of the aircraft. 


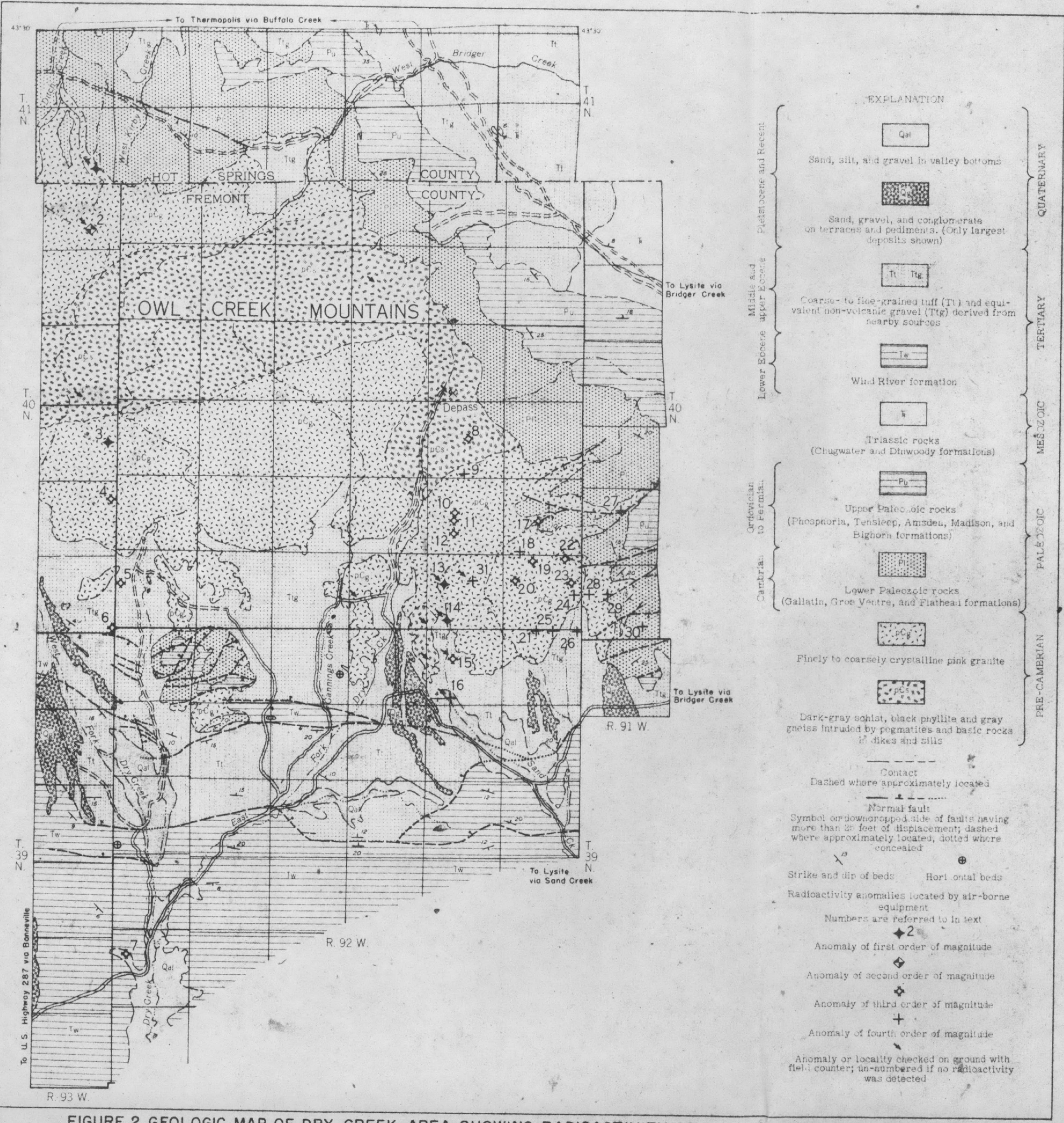

FIGURE 2 GEOLOGIC MAP OF DRY CREEK AREA SHOWING RADIOACTIVITY ANOMALIES DETECTED FROM AIR 
Of the 31 anomalies shown in figure 2, 22 are in pre-Cambrian granite, 5 are in middle and upper Eocene rocks largely derived from the granite, 2 are in alluvium derived either from the arkosic middle and upper Eocene rocks or from the Wind River formation that also is arkosic, 1 is in pre-Cambrian schist and gneiss, and 1 is in the Flathead sandstone.

The granite is remarkably uniform in color, grain size, and mineralogic composition. A few irregular zones are finer grained and harder than the main mass of granite and there are a few thin coarse-grained pegmatitic dikes. Otherwise, the pink granite weathers orange brown and consists of intergrown crystals of quartz and pink feldspar with a few small flakes of biotite. Jointing is prominent in two direction, east northeast and north-northwest. At many places nearly horizontal or moderately dipping sheeting gives a bedded appearance to the rock. Weathering and erosion has produced rounded block-like spires bounded by the joints. Many of the joints can be traced on air photos for a mile or more.

The location marked on the mosaic as the peak of the anomaly can be identified quite precisely on the ground, but portable Geiger counter readings in its vicinity vary little although samples from near each anomaly point vary somewhat in content of radioactive materials (table 1). Examination of the uniform granite with a Geiger counter was time consuming because of the lack of changes in lithology that might serve as targets for examination. Such examinations might have been made more profitably with a portable scintillometer as such an instrument is adapted to covering a large area rather quickly. Because of lack of time and the slowness of counter examination, the area examined around each anomaly point was small. The higher order anomalies were examined first and when no encouraging results were obtained。 little effort was made to examine the lower order anomalies which were in rugged terrain and difficult to reach. It is now known that the order of magnitude of the anomaly does not necessarily have a direct re lation to the amount of radioactivity on the ground. In consequence, some of the 4th order anomalies may be the result of more radioactivity that anomalies of higher orders.

The highest uranium content of the samples collected is 0.003 percent (table 1, sample 31a from 300 yards east of anomaly 31 on figure 2). The other granite samples contained only 0.001 or 0.002 percent uranium. The equivalent uranium content of the granite samples ranges from 2 to 5 times the uranium con tent. The radioactivity may be due chiefly to the presence of thorium or some daughter product of uranium. 
Table 1. Air-detected anomaliês

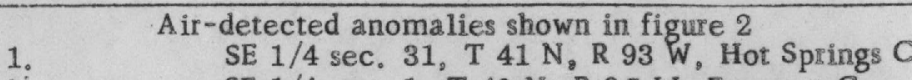

1. Air-detected anomaties $1 / 41 \mathrm{sec}, \mathrm{T}, \mathrm{R} 93 \mathrm{~W}$, Hot Springs $\mathrm{Co}$

Order of Ground

magnitude checked. Material and remarks

Counter NE $1 / 4$ sec. 24 T $40 \mathrm{~N}_{2} \mathrm{R} 93 \mathrm{~W}$, Fremont $\mathrm{Co}$.

Pre-Cambrian granite just beneath base of Flarhead sandstone

NW $1 / 4$, $31, T$ N, R 92 W Frem SW $1 / 4$ sec. 36 , T $40 \mathrm{~N}_{8} \mathrm{R} 93 \mathrm{~W}$, Fremont Co. NW $1 / 4 \mathrm{sec} .30, \mathrm{~T} 39 \mathrm{~N}, \mathrm{R} 92 \mathrm{~W}$, Fremont Co. NE $1 / 4$ sec. 23, T $40 \mathrm{~N}$, R $92 \mathrm{~W}$, Fremont Co. SW $1 / 4$ sec. 23 , T $40 \mathrm{~N}$, R $92 \mathrm{~W}$, Fremont Co. NW $1 / 4 \mathrm{sec}, 26, T 40 \mathrm{~N}, \mathrm{R} 92 \mathrm{~W}$, Fremont Co. SW $1 / 4$ sec. $26, T$ T $40 \mathrm{~N}$, R $92 \mathrm{~W}$, Fremont Co. SW $1 / 4 \mathrm{sec}, 26, \mathrm{~T} 40 \mathrm{~N}$, R $92 \mathrm{~W}$, Fremont $\mathrm{Co}_{0}$ NW $1 / 4 \mathrm{sec}, 35, \mathrm{~T} 40 \mathrm{~N}, \mathrm{R} 92 \mathrm{~W}$, Fremont Co. SW $1 / 4$ sec. 35, T 40 N, R 92 W, Fremont Co. NE $1 / 4$ sec, $2, T 39 \mathrm{~N}, \mathrm{R} 92 \mathrm{~W}$, Fremont Co. SW $1 / 4$ sec, 2, T 39 N, R 92 W, Fremont Co. 300 yards west of indicated point for 16 SW $1 / 4$ sec. 25 , T $40 \mathrm{~N}, \mathrm{R} 92 \mathrm{~W}$, Fremont Co. SW $1 / 4$ sec. 25 , T $40 \mathrm{~N}$, R $92 \mathrm{~W}$, Fremont $\mathrm{Co}_{0}$ NW 1/4 sec. $36, \mathrm{~T} 40 \mathrm{~N}, \mathrm{R} 92 \mathrm{~W}$, Fremont $\mathrm{Co}$ NW $1 / 4$ sec. $36, T 40 \mathrm{~N}, \mathrm{R} 92 \mathrm{~W}$, Fremont Co. NW $1 / 4$ sec. $1, T$ T 39 , R $92 \mathrm{~W}$, Fremont Co. NE $1 / 4$ sec. $36, T, 40 \mathrm{~N}, \mathrm{R} 92 \mathrm{~W}$, Fremont Co. NE $1 / 4$ sec. $36, T 40 \mathrm{~N}, \mathrm{R} 92 \mathrm{~W}$, Fremont Co. SE $1 / 4$. $36, T 0 \mathrm{~N}, \mathrm{R}-92 \mathrm{~W}$, Fremont Co. NE $1 / 4$ sec. $1, T 39 \mathrm{~N}, \mathrm{R} 92 \mathrm{~W}$, Fremont Co. NE $1 / 4$. $T$ T 39 R $92 \mathrm{~W}$. Fremont Co. NW $1 / 4$. NW $1 / 400.31, T 40$, $91 \mathrm{~W}$, Fremont $\mathrm{Co}_{0}$ NW 1/4 sec. $31,10 \mathrm{~N}, \mathrm{R} 1 \mathrm{~W}, \mathrm{Fremont} \mathrm{Co}$ W $1 / 4$ sec. $31,10 \mathrm{~N}, \mathrm{R}$, $\mathrm{W}, \mathrm{Fremont} \mathrm{Co}_{0}$ NE $1 / 4$ sec. 35 , T $40 \mathrm{~N}, \mathrm{R} 92 \mathrm{~W}$, Fremont Co. 300 yards east of indicated point for 31

Other localities shown in figure 1$)$

W $1 / 2 \mathrm{sec}, 17, \mathrm{~T} 5 \mathrm{~N}, \mathrm{R} 5 \mathrm{E}, \mathrm{Fremont} \mathrm{Co}$.

Middle \& upper Eocene gravel derived from pre-Cambrian rocks do

drom arkosic Wind River strat Pre-Cambrian schist and gneiss

Pre-Cambrian granit

do

do

Middle \& upper Eocene gravel derived from granite$$
\text { do }
$$

Arkosic Quaternary alluvium

Upper Eocene tuff

Pre-Cambrian granite

do

do

do

do

do

do

Middle and upper Eocene gravel derived from granite

Pre-Cambrian granite

do

ower Paleozoic rocks (Flathead sandstone)

Pre-Cambrian granite

$4-8$

$5-18$

52848

$0.005 \quad 0.002$

SE $1 / 4 \mathrm{sec}, 10, \mathrm{~T} 5 \mathrm{~N}, \mathrm{R} 5 \mathrm{E}$, Fremont Co. NE $1 / 4$ sec. 19 , T $39 \mathrm{~N}_{\text {, R }} 92 \mathrm{~W}$, Fremont Co. sec, 35, T $42 \mathrm{~N}, \mathrm{R} 90 \mathrm{~W}$, Hot Springs Co.
Carbonaceous shale below middle and upper Eocene tuffaceous rocks and tuffaceous rocks

Middle - upper Eocene tuff

Carbonaceous shale, Coal $0-3.2$ ' thick

Tuff $0.7^{\circ}$ thick

Burned rock and ash

Yes
Coal in Lance (?) formation
$52847 \cdot 0.004 \quad 0.002$

$\begin{array}{lll}52846 & 0.005 & 0.002\end{array}$

$52845 \quad 0.005 \quad 0.002$

$52844 \quad 0.004 \quad 0.001$

$\begin{array}{lll}52850 & 0.004 & 0.003\end{array}$ 
As most of the radioactivity at the anomalies tested is not the result of uranium, it is not likely that any of the anomalies that were not checked are the result of uranium in commercial amounts.

Anomalies 17, 27, and 29 appear to fall very close to faults along which lower Paleozoic rocks (chiefly the Cambrian Flathead sandstone) are dropped down against granite. The anomalies probably are in the granite rather than the faults, and their apparent relationship to the faults is probably the result of lack of correction of the records for lag, and for flight line position.

The middle and upper Eocene gravel in which 5 anomalies are located consists of coarsely gritty and gravelly claystone, clayey sandstone, and conglomeratic sandstone derived from the pre-Cambrian granite. The sedimentary rock thus has a composition similar to the granite and the radioactivity is believed to be also due to thorium or daughter products of uranium. The same is true of the anomalies located in the Quaternaty alluvium. The alluvium at anomaly 16 is derived both from the granite and also from the arkosic middle and upper Eocene rocks. The alluvium at anomaly 7 is derived from the arkosic Wind River formation that was derived from erosion of the granite. Anomaly 30, in the Flathead sandstone also may be due to thorium as the Flathead, too, contains much quartz and feldspar derived from the underlying granite.

A sample of middle and upper Eocene tuff collected 300 yards west of anomaly 16 contained 0.004 percent equivalent uranium and 0.003 percent uranium (table 1 , sample 16a). The ratio of eU to $U$ in the tuff is notably different from the ratio in the granite samples.

\section{OTHER LOCALITIES}

The middle and upper Eocene tuff sequence also was examined in T. 5 N., R. 5 E., west of the Bighorn River. At locality 32 (fig. 1), lignite and carbonaceous shale occur in the brightly colored tuffs in the lower part of the sequence. The highest counter reading from the carbonaceous shale was 8 on the 0.2 scale. The upper part of the sequence consists of drab olive-green coarse-grained to fine-grained tuffs in which are several beds of carbonaceous shale. The highest counter reading from the tuff was 8 on the 0.2 scale. These upper rocks and those at locality 33,3 to 4 miles to the northeast, where counter readings reached a high of 6 on the 0.2 scale, are similar in age and lithologic type to those in the Dry Creek Area.

At locality 34, T. 39 N., R. 92 W., lignite beds in the lower Eocene Wind River formation were tested with a counter and found to be practically non radioactive. 
None of the four samples of coal, tuff, and clinker in the tuffaceous oil shale unit in the lower part of the sequence at Lysite Mountain (locality 35) contained more than 0.001 percent uranium. The tuffs above the oil shale are practically non radioactive, according to the counter.

Coals and carbonaceous shales in the Meeteetse and Frontier formations in the Shotgun Butte area were tested by Max Troyer and found to be non radioactive. J. D. Love tested a coal in the lower part of the Lance (?) formation (locality 36) along the Powder River lineament; no significant radioactivity was detected. Carbonaceous shales and tuffs in the upper part of the Frontier formation near Ervay in the Rattlesnake Hills, were also tested by Love but no significant radioactivity was detected.

\section{CONCLUSIONS}

Detailed investigations of middle and upper Eocene tuffs and the carbonaceous rocks associated with them in the northeastern part of the Wind River Basin do not seem warranted by the present information. However, the middle and upper Eocene rocks will be tested when there is an opportunity to do so in connection with other work because the examination made so far is not complete. Additional work may be done in the preCambrian rocks in the Dry Creek area. The work should be done with the aid of a scintillometer and the positions of the anomalies recorded by airborne reconnaissance should be corrected for lag and possible flight line error. However, further work is planned definitely at this time. 


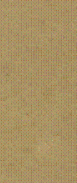


